Extrême-Orient Extrême-Occident

\section{Extrême-Orient Extrême-Occident}

$37 \mid 2014$

Penser les épidémies depuis la Chine, le Japon et la Corée

\title{
Epidemic Cerebrospinal Meningitis during the Cultural Revolution
}

L'épidémie de méningite cérébro-spinale pendant la Révolution culturelle 文革時期流行性膍脊髓膜炎大流行原因初探

\section{Ka wai Fan}

\section{OpenEdition \\ Journals}

\section{Electronic version}

URL: http://journals.openedition.org/extremeorient/341

DOI: 10.4000/extremeorient.341

ISSN: 2108-7105

\section{Publisher}

Presses universitaires de Vincennes

\section{Printed version}

Date of publication: 1 September 2014

Number of pages: 197-232

ISBN: 978-2-84292-411-9

ISSN: 0754-5010

\section{Electronic reference}

Ka wai Fan, «Epidemic Cerebrospinal Meningitis during the Cultural Revolution », Extrême-Orient Extrême-Occident [Online], 37 | 2014, Online since 01 September 2017, connection on 30 April 2019. URL : http://journals.openedition.org/extremeorient/341; DOI : 10.4000/extremeorient.341 


\title{
Epidemic Cerebrospinal Meningitis during the Cultural Revolution
}

\author{
Fan Ka wai ${ }^{1}$
}

\section{Introduction}

Following the foundation of the People's Republic of China (PRC), a program of public health reform was launched by the Communist Party of China (CPC) to shape the structure of the health care system. Four key principles were to guide the implementation of this system: the health care system should serve the workers, peasants, and soldiers; disease prevention should be prioritized over curative programs; Chinese medicine should be combined with Western medicine; and health promoting work should be carried out through mass movements. These principles underpinned the central values of public health care during the early years of the PRC, where disease prevention was thus given high priority. ${ }^{2}$

At first, the disease prevention policies were directed at smallpox, plague and cholera. However, following the start of the Korean War in 1952, the CPC Central Committee suspected that the United States was engaged in biological warfare. ${ }^{3}$ This prompted the CPC to start the Patriotic Health Campaigns (Aiguo weisheng): first providing information on health threats caused by disease-spreading insects that, in this context of suspicions of biological warfare, should be systematically destroyed. Similar campaigns were later launched for the prevention of other diseases. In 1956, for instance, Chairman Mao launched the anti-schistosomiasis campaign in the southern provinces of

1. I would like to thank my three students Shum Wai, Ho Hinchi and Cheung Tinghei. We discussed this topic in July 2012. They inspired me to investigate this topic further. I have received a great deal of help from Prof. Lai Honkei of Sun Yat-Sen University in collecting research materials.

2. Chen 2007: 456-482.

3. Endicoot 1998. 
China, with the slogan "aiguo weisheng." The aim was to improve agriculture and water conservation, in order to enhance agricultural production and to eliminate schistosomiasis, thanks to mass mobilization. ${ }^{4}$

The Patriotic Health Campaigns, which made wide use of propaganda posters and pamphlets, were seen as effective means for implementing hygiene and disease prevention measures through mass mobilization. Above all, these campaigns showcased the consistent political approach adopted by the CPC in mobilizing the masses to attain the goals of central government. ${ }^{5}$

While the CPC was engaged in programs for the elimination of a number of diseases, its policies however encouraged the spread of others. During 1966 and 1967, after the Cultural Revolution had been launched and nationwide gatherings of students and Red Guards (Hong wei bing) were encouraged, an outbreak of cerebrospinal meningitis spread throughout the country, causing over 160,000 deaths. ${ }^{6}$ This outbreak did not reach high visibility, due to the successes that the CPC achieved in controlling smallpox, cholera, plague, tuberculosis, and malaria. ${ }^{7}$ And this particular outbreak of cerebrospinal meningitis has generally been neglected by historians in their worldwide history of the disease. ${ }^{8}$

Drawing on provincial archives, health gazetteers (weishengzhi) and local gazetteers (difangzhi) published in various provinces and counties during 1980-2000, as well as on notices, documents and handbooks distributed for preventing cerebrospinal meningitis in the 1960s, this article traces the course of the 1966-1967 cerebrospinal meningitis epidemic, and sheds light on the factors that led to this acute and nationwide epidemic.

\section{Epidemic cerebrospinal meningitis in Beijing and nationwide}

Epidemic cerebrospinal meningitis, caused by meningococcus Neisseria meningitidis serogroup A in China, is a bacterial form of meningitis, caused by the inflammation of the protective membranes covering the brain and the spinal cord. The bacterium spreads through contact with saliva from an

4. Fan 2008: 176-187; Gross 2010.

5. Xiao 2004: 498-514; Rogaski 2004: 285-299; Hu 2013: 94-117; Fan 2010: 277-293; Hung 2010: 400-420.

6. Zuo 1997: 12; Patterson 1993: 878; National Immunization Program, Chinese Center for Disease Control and Prevention.

7. Cui 1986: 28-35; Hipgrave 2011: 224-238.

8. Schwartz 1989: S 118-124; Baltimore 2009: 495-517. 
infected, and possibly asymptomatic, person. Typically transmission occurs through coughing, sneezing, kissing or sharing drinking vessels, and the like. Epidemic cerebrospinal meningitis has a high mortality rate. ${ }^{9}$

As modern epidemiological studies have shown, several conditions usually contribute to the outbreak of an epidemic of cerebrospinal meningitis. First, because the disease infects tissues in patients' and carriers' throats, speaking, coughing, or sneezing can spread the virus through the air, resulting in a dramatic increase in the number of people infected in a short period of time. The likelihood of transmission is particularly high in non-ventilated environments. Second, climatic factors play an important role in the seasonal upsurge of meningococcal diseases. In China, the disease is extremely common in winter and early spring. Third, meningococcal diseases attain epidemic levels in places such as college campuses and barracks during mobilizations, where many people are living together for the first time. Fourth, travelling facilitates the circulation of the disease inside a country, or from country to country. In particular, since gatherings of susceptible people represent an important risk factor for outbreaks, large population movements play a major role in the spread of infection and diseases. Fifth, poor living conditions and overcrowded housing are linked with a higher incidence of meningococcal diseases. Sixth, young adults, children, the elderly, and peasants are particularly vulnerable to meningococcal disease. Finally, people in some remote regions may lack immunity to the disease; thus, when the disease invades that area, an epidemic is highly probable. ${ }^{10}$

The cerebrospinal meningitis epidemic cycle is 10 years in China. The disease was prevalent in China in 1957, 1967 and 1977. ${ }^{11}$ From autumn 1966 to spring 1967, the disease began to spread, and became epidemic in every major city. Afterward, it rapidly spread to medium-sized and smaller cities, as well as remote and border areas. The incidence rate in 1967 was 403/100,000 people, that is four times higher than the incidence rate in 1975 , which was the highest rate since records began. ${ }^{12}$ From 1966 to 1967, the disease affected most provinces, and started to decline in $1968 .{ }^{13}$

9. For more details from medical perspective, see World Health Organization 1998.

10. World Health Organization 1998: 15; Saez-Liorens 2003; Umaru 2013: 1-30. For epidemiological characteristics of Cerebrospinal Meningitis in China, see Xue 2009: 26-35.

11. Hu 1981: 61 .

12. In 1975, 100/100,000 was defined as the highest incidence of the epidemic cerebrospinal meningitis. See Hu 1981: 61; Wang 1992: 5267-5282.

13. Huang 2009: 343-344. 
Fan Ka wai

\begin{tabular}{|c|c|c|}
\hline Province & Case (year) & Incidence rate (per 100,000$)$ \\
\hline Anhui & $254,961(1967)$ & $740.6(1967)$ \\
\hline Fujian & $92,686(1967)$ & $\begin{array}{l}51.59(1966) \\
502.12(1967) \\
\end{array}$ \\
\hline Gansu & $7,978(1967)$ & $55.48(1967)$ \\
\hline Guangdong & $\begin{array}{l}5,810(1966) \\
312,658(1967) \\
54,930(1968) \\
\end{array}$ & $\begin{array}{l}13.47(1966) \\
705.04(1967) \\
120.6(1968) \\
\end{array}$ \\
\hline Guangxi & $\begin{array}{l}123,864(1967) \\
43,820(1968)\end{array}$ & $\begin{array}{l}482.49(1967) \\
167(1968)\end{array}$ \\
\hline Hainan & $4,452(1967)$ & $115.6(1967)$ \\
\hline Hebei & $101,838(1967)$ & $\begin{array}{l}153.85(1966) \\
274.26(1967)\end{array}$ \\
\hline Heilongjiang & $38,900(1967)$ & $174.34(1967)$ \\
\hline Henan & $356,082(1967)$ & $\begin{array}{l}244.5(1966) \\
646.6(1967)\end{array}$ \\
\hline Hubei & $421,065(1967)$ & \\
\hline Hunan & $164,902(1966)$ & $\begin{array}{l}16.21(1966) \\
400(1967)\end{array}$ \\
\hline Jiangsu & $170,166(1967)$ & \\
\hline Jiangxi & $265,000(1967)$ & $1140.6(1967)$ \\
\hline Jilin & $7,289(1966)$ & $161.21(1967)$ \\
\hline Liaoning & $51,931(1967)$ & $177.97(1967)$ \\
\hline Ningxia & $3,654(1967)$ & $376(1967)$ \\
\hline Qinghai & $843(1967)$ & \\
\hline Shaanxi & 39,754 (1966) & $\begin{array}{l}78.50(1966) \\
177.16(1967) \\
\end{array}$ \\
\hline Shandong & $336,666(1966)$ & $\begin{array}{l}120.71(1966) \\
564.12(1967) \\
187.97(1968) \\
\end{array}$ \\
\hline Shanxi & $26,616(1967)$ & $136.71(1967)$ \\
\hline Sichuan & $122,155(1967)$ & $163.29(1967)$ \\
\hline Xinjiang & $7,090(1967)$ & $82.932(1967)$ \\
\hline
\end{tabular}

Figure 1. Incidence of cerebrospinal meningitis in 1966 and 1967

Sources ${ }^{14}$ : Anhuishengzhi Weishengzhi 1996: 298; Fujiansheng weisheng fangyi zhan yewu ke 1975: 37-42; Gansushengzhi Weishengzhi 1995: 127; Guangdongshengzhi Weishengzhi

14. Health gazetteers do not usually cite the references from which they extract numbers and information, so we are never sure where the numbers came from. Although the figures are not totally reliable, they may reflect the trend of the dissemination of epidemic cerebrospinal meningitis over the early period of the Cultural Revolution, 
2003: 173; Guangxitongzhi Yiliaoweishengzhi 1999: 133; Hainanshengzhi Weishengzhi 2001: 112; Hebeisheng weisheng fangyi zhan 1975: 50-62; Heilongjiangshengzhi Weishengzhi 1988: 120; Henanshengzhi Weishengzhi 1991: 212; Deng 2006: 621; Hunansheng weisheng fangyi zhan: 63-75; Jiangsushengzhi Weishengzhi 2003: 296. Deng 2006: 621; Jiangxisheng Weishengzhi 1997: 177; Jilinshengzhi Weishengzhi 1992: 36; Liaoningshengzhi Weishengzhi 1999: 76; Deng 2006: 621; Shaanxishengzhi Weishengzhi 1996: 185; Shandongsheng weishengzhi 1992: 365; Shanxisheng shizhi yanjiuyua 1997: 455; Sichuansheng zhi yiyao weishengzhi 1995: 142-143; Xinjiang tongzhi weishengzhi 1996: 130.

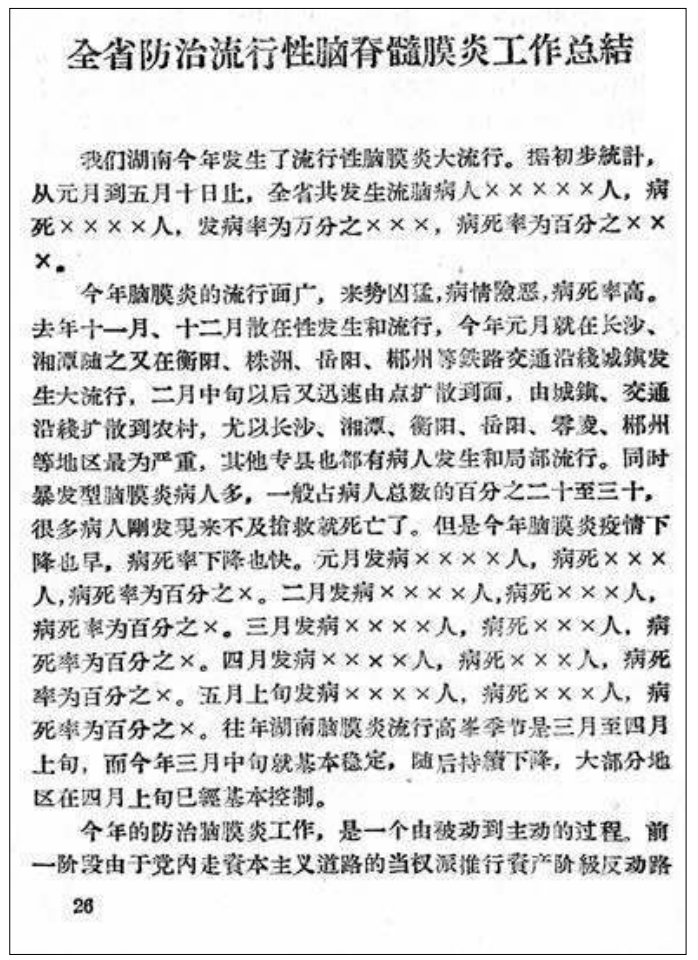

\section{Picture 1}

This picture shows that the number of epidemic cerebrospinal meningitis infected patients (xxx) was not disclosed. "Quansheng fangzhi liuxingxing naojisuimoyan gongzuo zongjie" 1967: 26. (C) Fan Ka wai.

for which we have no other figures. As picture 1 shows (xxx), the CPC had not released any official figures regarding the epidemic at that time. In a meeting, Zhou Enlai discussed with representatives from the rebel factions whether to publish the confidential figures pertaining to the meningitis epidemic. Zhonggong zhongyao lishi wenxian ziliao huibian1997, vol. 13, no. 7: 216-232. 
Fan Ka wai

\section{毛主庴语录}

你们要关心国家大事, 要把无产 阶级文化大革命进行到底！

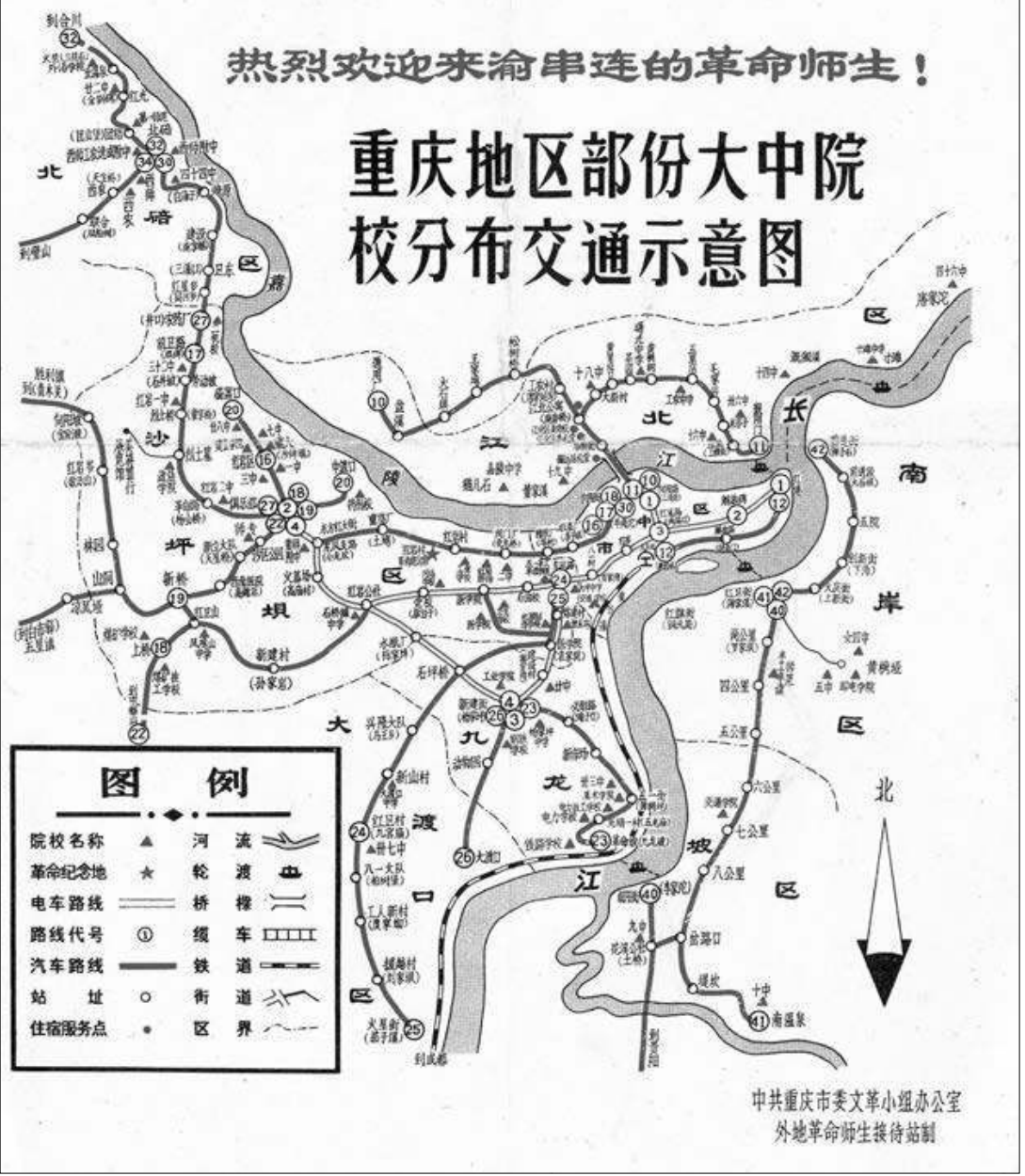

Picture 2

The map for Great Networking at Chongqing city. (C) Fan Ka wai. 
Figures available for 1966, 1967, and 1968 (Fig. 1) clearly show that the epidemic peaked from 1966 to 1967 and declined afterward. However, Figure 2 indicates that the epidemic's spread in Beijing differed from the provinces.

\begin{tabular}{|l|l|l|l|l|}
\hline Year & Infected people & Incidence (per 100,000) & Deaths & Death rate \\
\hline 1966 & 22061 & 279.61 & 873 & 11.06 \\
\hline 1967 & 10301 & 130.87 & 335 & 4.26 \\
\hline 1968 & 2013 & 25.21 & 90 & 1.13 \\
\hline
\end{tabular}

Figure 2. The data of cerebrospinal meningitis in beijing from 1966 to 1968

Source: Beijingzhi weishengzhi 2003: 171.

As indicated by the statistics, in Beijing the epidemic reached its peak in 1966 and declined in 1967, while in the provinces, the epidemic reached its peak in 1967. To understand why the disease spread so widely and quickly in the provinces, we need to look more closely at the social and political events of the Cultural Revolution.

\section{The Great Networking Movement within the Cultural Revolution}

The Cultural Revolution started in 1966 with the publication of a number of Central Documents by the CPC. In one of these documents, the 'May 16 Notification,' Chairman Mao Zedong called upon students, who would come to play a vital role in contemporary Chinese history, to actively promote his reforms. Students gathered from all over China to form the Red Guards (Hong wei bing $)^{15}$, and initiated a campaign to eradicate the 'Four Olds' (Si Jiu: Old Customs, Old Culture, Old Habits, and Old Ideas). This mass reform movement soon got out of control and led to a series of tragedies. ${ }^{16}$

Before September 5, 1966, every university in Beijing had put up posters advertising the Cultural Revolution. From this date, the CPC Central Committee requested that China's university and secondary school representatives go to Beijing to observe the Cultural Revolution. Over ten thousand students and teachers were mobilized in a nationwide movement. Nationwide, Red Guards left their homes to go to Beijing and other sacred places of the Revolution to exchange their revolutionary experience, and spread the flame of revolution

15. For more information on the Red Guards, see Chan 1985; Walder 2009.

16. See notably Yan 1989: 75-88; Wang 1996: 127-138. 
all over the country, in a mass movement known as the 'Great Networking' or 'National Great Networking' (Dachuanlian or Quanguodachuanlian). ${ }^{17}$

Most of the Red Guards from outside the capital set Beijing as their final destination in order to meet and pay homage to Chairman Mao, and share their revolutionary fervor and experience. ${ }^{18}$ The Red Guards who were based in Beijing set out for various key sites, assembling especially in the sacred places of the communist revolution, such as the Jinggang Mountains, Yan'an, Dazhai, Zunyi, Shaoshan ${ }^{19}$ and Guangzhou (the biggest city in the south). It was a way of rekindling in the present the revolutionary spirit of the past. ${ }^{20}$ A proclamation of December 1 mentioned that Beijing, Shaoshan, Jinggang Mountains (visited by 900,000 Red Guards during the Networking Movement) ${ }^{21}$, Zunyi, and Yan'an were overcrowded with revolutionary teachers and students. ${ }^{22}$

Schooling was suspended nationwide, and the Great Networking stretched from North to South and from West to East. ${ }^{23}$ This movement led to chaos in China, paralyzing railways and crowding dwellings. As Deng Tietao and MacFarquhar Roderick highlighted, this mass mobilization also triggered a cerebrospinal meningitis epidemic across the country. According to MacFarquhar Roderick, before the autumn of 1966, outbreaks of epidemic cerebral-spinal meningitis were rare in China, and highly localized, in large part because of a low degree of popular mobility. The sudden mobilization of millions of people from every corner of the country in extremely cramped and unsanitary conditions put an end to this situation and paved the way for a massive epidemic. This contribution examines the ways this epidemic spread

17. On the Great Networking Movement, see Guo 2006: 105-107; Yang 2000: 379-406; Yan 1993.

18. Bu 2008: 329-332.

19. These places had something special: the Jinggang Moutains in Hunan were regarded as the cradle of the CPC, since Mao had led a group of peasants there in 1926. Yan'an, in Shaanxi, had been the base of the Chinese Communist Party from 1935 to 1949. It was also the end of the Long March (10/1934-10/1936). Dazhai village, in Shanxi, was chosen to implement the agricultural model that Mao proposed in 1963. Zunyi, in Guizhou province, had been the place of a crucial CPC meeting in January 1935. Shaoshan, in Hunan province, is the birth place of Mao Zedong.

20. Denton 2012: 248.

21. The local gazetteer reported 300 cases of epidemic cerebrospinal meningitis and the death of 18 patients Jinggangshanzhi 1997: 25, 578.

22. CCP Documents of the Great Proletarian Cultural Revolution 1966-1967 1968 (01.12.1966): 125-126; (03.02.1967): 225-226.

23. Yan 1989: 129-135; Bu 2008: 255-269. In China, the spread pattern of the epidemic cerebrospinal meningitis is from the northern to southern region. Wu 1991: 136-139. 
all over the country and how the authorities, sharing contradicting views, and belonging to different factions within the CPC, dealt with this epidemic. ${ }^{24}$

The political agenda of this movement was, in fact, inextricably linked with the spread of the disease. On August 8, 1966, Chairman Mao greeted the national representatives of the Red Guards for the first time at Tiananmen Square, in Beijing. From August to November 1966, 1.1 million students flocked to Beijing to worship Chairman Mao. ${ }^{25}$ However, Chairman Mao was not satisfied and believed that Beijing could receive up to three million Red Guards. ${ }^{26}$ To reach this goal, the central and local governments provided free transportation, food, accommodation, and medical services to the Red Guards, who also received support from their schools and local units in travelling to Beijing. ${ }^{27}$ The central government and State Council originally allowed students and representatives of the Red Guards to stay in Beijing for just four days. However, some newcomers considered this as an opportunity to see Chairman Mao in person. As a result, Beijing was even more crowded than usual as hundreds of thousands of students waited for a meeting with Mao. During their stay in Beijing, students relied on local schools for accommodation, sleeping on floors and sharing poor living conditions, which favored the spread of the disease. ${ }^{28}$ Meanwhile, since winter had arrived, cold weather provided an environment that further encouraged the virus and facilitated the spread of the disease. During this mobilization, there were 22,061 cases of meningitis reported in Beijing in the second half of 1966, with an incidence rate of $279.61 / 100,000$, and a death rate of 11.06 (873 deaths). That year, the epidemic mostly affected Beijing. Although the CPC Central Committee was aware of the problem, it did not devise strategies to counter the situation. ${ }^{29}$ With ten thousand provincial students already ill in Beijing at that time, the Central Committee's response was not providing them with treatment, but encouraging

24. Deng 2006: 620-624 and MacFarquhar \& Schoenhals 2006: 113.

25. Zhonggong zhongyao lishi wenxian ziliao huibian 1997, vol. 13, no. 4: 74.

26. Zhonggong zhongyao lishi wenxian ziliao huibian 1997, vol. 13, no. 4: 73-76; vol. 13, no. 2: 268 .

27. Zhonggong zhongyao lishi wenxian ziliao huibian 1997, vol. 13, no. 4: 56-57.

28. The historian Ge Zhaoguang recalled his experience of participating in the Great Networking Movement, traveling from Guiyang to Beijing by train in 1966. He described the poor living condition when he was staying at Tsinghua University, Beijing. Ge 2011. Overcrowded sleeping arrangements is an important factor in the spread of the disease. See Baltimore 2009: 500-501.

29. Zhonggong zhongyao lishi wenxian ziliao huibian 1997, vol. 13, no. 2: 240; vol. 13, no. 2: 265; vol. 13, no. 2: 268. Hospitals in Beijing were full of patients who suffered from respiratory and digestive disease. Zhang 1997: 22-24. 
the sufferers to go home. ${ }^{30}$ Without adequate preventive measures, the epidemic spread from Beijing to every corner of the country, in the following months.

However, Beijing was not the only place the students gathered. Guangzhou, the biggest metropolis and transportation hub in the south, which had received over 1.6 million Red Guards by the end of 1966, was also a popular place for students to visit in order to exchange their revolutionary experience. ${ }^{31}$ Likewise, Red Guards from all over the country travelled by rail to Hunan province, home to many important cities and symbolic places such as Shaoshan, Mao's birthplace. By November 1966, the disease had reached a number of cities and counties in Hunan. It started to spread from the highway connecting Changsha and Shaoshan, which concentrated the largest population mobilization. The disease not only spread to Zhuzhou, Hengyang, Yueyang, Chenzhou, but also to the cities on the railway, and villages on both sides of the railway and highway. By February 1967, the disease had become epidemic in Hunan and Guangdong provinces. ${ }^{32}$ In Guangdong province, the first cases of the disease were discovered in Xinhui, Yangchun, and Liannan Yaozu Zizhi counties in 1967. The disease quickly spread throughout the People's Communes Renmin gongshe, the basic rural administrative organization at village level in China from 1958 to 1983. Five students in Zhoubei and two in Guandu of Wengyuan county were infected and died of the disease during the Great Networking Movement. ${ }^{33}$

At the end of 1966, the national Great Networking Movement unexpectedly moved in two new directions. Firstly, the movement which had primarily been reserved to students was joined by workers. Secondly, the movement, which had originally only focused on cities and revolutionary shrines, was extended to villages. Actually, on September 14, 1966, the CPC Central Committee had prohibited students and Red Guards from Beijing and other regions from

30. CCP Documents of the Great Proletarian Cultural Revolution 1966-1967 1968 (12.11.1966): 96-97.

31. In December 1966, Over 1.6 million Red Guards from various provinces had reached Guangzhou for the Great Networking Movement, a destination widely encouraged by the central government. GuangzhoushizhiGongchandangzhi 1997: 173; Zhonggong zhongyao lishi wenxian ziliao huibian 1997, vol. 13, no. 2: 73.

32. Hunanshengzhi Yiyaoweishengzhi 1988: 163. Deng 2006: 623 cites an archival document related to the epidemic in Guangdong province. In this province, the disease spread widely along the Guangzhou-Zhanjiang highway. Heshanxianzhi 2001: 606. In Shanxi province, the disease also spread along the railway. Shanxitongzhi Weisheng Yiyaozhi Weishengpian 1997: 455.

33. For more examples, see Xinhuixianzhi 1995: 1002; Yangchunxianzhi 1996: 886; LiannanYaozu Zizhixianxianzhi 1996: 610; Wengyuanxianzhi 1997: 776. 
entering villages below county level. Moreover, officials and village students below county level were not allowed to participate in the Great Networking Movement. ${ }^{34}$ However, on December 15, 1966, the CPC Central Committee ordered that the Cultural Revolution should be promoted in villages, as well, and that Red Guards should be formed there. Revolutionary students were now permitted to enter villages. ${ }^{35}$ This political change facilitated the transmission of the disease from cities to villages. Figure 3, drawn from health gazetteers from many counties in Guangdong province, shows that the disease not only appeared in Guangzhou city, but was also widespread in villages all over Guangdong province. ${ }^{36}$

With this change of policy, from winter 1966 to spring 1967, the disease became prevalent in all the major cities, and also reached remote districts, small towns, villages, the People's Communes, and brigades ${ }^{37}$ along the railways and highways.

Transporting huge numbers of Red Guards all over China overwhelmed the railway system, and seriously affected the transportation of ordinary resources. ${ }^{38}$ Premier Zhou Enlai was deeply concerned that the Great Networking Movement which had paralyzed traffic across China, interrupting the supply of important goods and materials, would cause delays in reaching the objectives of the third five-year plan (1966-1970). To solve this problem, the central government took another decision that would later impact on the spread of the epidemic: while it did not stop the Great Networking Movement, it advised Red Guards and students to continue the movement on foot; central and local governments would no longer supply free transportation.

34. CCP Documents of the Great Proletarian Cultural Revolution 1966-1967 1968 (15.12.1966): 137-138.

35. CCP Documents of the Great Proletarian Cultural Revolution 1966-1967 1968 (14.09.1966): 77-78; Zhonggong zhongyao lishi wenxian ziliao huibian 1997, vol. 13, no. 5: 129; Red Guards also considered that they should go to the villages and promote the revolutionary experience to the peasants. Zhang 2003: 136.

36. The records of Zhongshan city, Zhaoqing city, Raoping county, Fengshun county, Luoding county, Pingyuan county, Hua county and Wuhua county stated that the disease was brought from other places by the students participating in the Great Networking Movement. The first case of the disease in Sanshui county was discovered in 1967, and the patient was a student from another province. Also, the first case of the disease in Hua county was discovered in 1966, and the patient was a Shanghai student. Sanshuixianzhi 1995: 1217. Huaxianzhi 1995: 802.

37. In Wuhua county, for instance, the disease was prevalent in 15 People's Communes, 3 towns and 313 brigades in 1967. Wuhuaxianzhi 1991: 551.

38. Chen 1987: 162; Liu 2006: 102-123. 
On October 3, 1966, the People's Daily (Renmin ribao) published a headline, "The Red Guards do not fear a long march," ${ }^{39}$ to inspire the Red Guards to share their revolutionary experience through walking. This measure, which was intended to improve the economy of the country, and to avoid congestion in major hub cities such as Chongqing (picture 2), Guangzhou, and Changsha, indirectly facilitated the spread of the epidemic into villages and remote areas of the country that had been left untouched by the disease because they were too far from railways. It notably provided further opportunities for Red Guards to share their revolutionary experience in small towns and villages, and to communicate with peasants in more remote areas, who typically lacked immunity to meningitis, and thus were more easily infected. ${ }^{40}$

Knowledge about methods of prevention and a cure for cerebrospinal meningitis was however available in the medical community in China at that time. In 1961, a book, Prevention and Treatment of Epidemic Cerebrospinal Meningitis, was published by Dr. Wang Qihuang, from Shanghai Ruijin Hospital's Department of Infectious Diseases. This book described how to prevent and cure the disease in 1950s China. It thoroughly reported six key facts relating to cerebrospinal meningitis: first, the disease usually occurred during the winter and spring seasons; second, patients were usually children; third, bacteria carriers were the source of the disease; fourth, it was necessary to keep indoor air pure and fresh; fifth, people needed to wear masks when they went to public assemblies or places of entertainment because these places were usually crowded, with turbid air; sixth, people should adopt indoor air sterilization when they were staying at epidemic-affected areas, or places with a high bacteria carrier rate. In terms of treatment, some effective methods for curing the disease were known and available, such as multiple sulfa drugs and antibiotics, and even some treatments using Chinese medicine. The book also pointed out that the Chinese New Year period was a period when this disease could spread widely and easily, as, before and after the Chinese New Year, people used to gather at places of entertainment, took public transport and visited shops. ${ }^{41}$ Dr. Wang's book finally stated that when measures had been vigorously enforced by the CPC, the death toll from cerebrospinal meningitis had greatly reduced, and the incidence of the disease also apparently had

39. "Hongweibing bupa yuanzheng nan" 1966.

40. The revolutionary organizations published a notice which stated that the Great Networking Movement was a great and new creation, and urged students not to stay in big cities but to learn from the workers and the peasants. Zhonggong zhongyao lishi wenxian ziliao huibian 1997, vol. 13, no. 2: 270.

41. Wang 1961. 
declined in the 1950s. ${ }^{42}$ In the 1960 s, the medical community in China had thus the proper skills and knowledge to have the disease under control.

Given the resources available at the time, putting an end to the Great Networking Movement when the disease had appeared in Beijing, in 1966, would have been the most effective way to halt the spread of the disease. However, several political factors, including Mao's utopist ideal of mass mobilizations, outbursts of enthusiasm by students and political struggles among different CPC factions hindered such a resolution. In addition, no one dared to openly blame the movement and its actors through of the fear of being accused of counter-revolutionary crime, publicly criticized and violently beaten. During this period (throughout the country) a significant number of people were beaten to death. ${ }^{43}$ In 1966, Chairman Mao's movement could not be easily stopped because Mao's utopist ideology was stronger than the Ministry of Health. While Premier Zhou ordered that students and Red Guards should not use railways in late 1966, because the transportation system was severely interrupted by the movement, it was impossible to stop the trend immediately. In some cases, students ignored the order, and continued to travel in trains.

In November 1966, as the traffic congestion situation worsened, the CPC Central Committee decided to temporarily halt the Great Networking Movement, and ordered students to participate in the revolutionary movement in their respective hometowns until the next spring when the movement would start again. ${ }^{44}$ The central committee of the CPC stopped calling upon students to gather at Beijing and the sacred places of revolution. Instead, it encouraged students to congregate with their neighbors and launch the revolution at home. It provided free tickets and accommodation to leave Beijing and return home, and re-opened schools.

42. Wang 1961.

43. Red Guards committed many acts of violence. See Wang 1996: 17-36; White 1989; Lu 1995: 533-542. The office of meningitis in Guangdong province stated that enemies of the people spread the rumor that "eradicating four olds caused epidemic cerebrospinal meningitis." Guangdongsheng liunao office 1967: 59.

44. CCP Documents of the Great Proletarian Cultural Revolution 1966-1967 1968 (16.11.1966): 107-108. 


\section{Final decision on the termination of the Great Networking Movement}

By early 1967 the epidemic had spread throughout China, which made it very difficult to control. Coming under pressure from local authorities, the CPC Central Committee and State Council addressed the epidemic from February 1967.

Some local authorities issued announcements to publicly address the problems of the epidemic in February 1967. For example, on February 7, 1967, an emergency notification was issued by the town government of Huangshi in Hubei province. The notification's title was, "We urge you to fight against Epidemic Cerebrospinal Meningitis," and pointed out that epidemic cerebrospinal meningitis was rampant in Huangshi town and Daye village. The number of patients was growing, and the onset of the disease was acute, with high mortality. Meanwhile, it also stated: "Next spring there will be millions of young revolutionaries arriving at our city, leaving other cities and going straight to the heart of our country in order to share their revolutionary experience; therefore, to prevent and eradicate the disease, we must put the topic down in our agenda, so that all people will place extra emphasis on the matter." ${ }^{45}$ This notification was announced in view of the next population mobilization, and Huangshi town had to prepare disease prevention measures to face the restoration of the Great Networking Movement in April.

Other provinces lacked medicines. A CIA report stressed that the chaos and mobilization caused by the Cultural Revolution had led to the transmission of the disease, and in provinces like Guangdong, the epidemic was out of control due to the shortage of sulfadiazine-a drug used in the prevention and treatment of the disease. In fact, in February 1967, severe shortages of sulfadiazine began to occur elsewhere, leading many Chinese people to turn to traditional medicine. Local health units placed urgent calls to higher echelons for supplies of sulfadiazine. ${ }^{46}$

In the face of such a severe situation and aware of warnings from many local authorities, the CPC Central Committee issued a proclamation on

45. "Zui jinji huxu jinji dongyuan qilai wei xunsu pumie liunao er douzheng” 1967.

46. Carey 1967. Although the United States of America (US) did not have much information relating to the Chinese outbreak of epidemic cerebrospinal meningitis, US officials were extremely concerned, believing that the situation was both serious and unprecedented. In Hong Kong, the CIA communicated with the travelers travelling between Hong Kong and Guangzhou in an effort to understand the circumstances of the epidemic in mainland China from 1966-1967. 
19 March, 1967 which cancelled the previous plan to restore the movement in spring 1967. ${ }^{47}$ At the same time, the CPC Central Committee decided to restore school classes so that students could participate in the revolution while they were in their hometowns, and pursuing their education, at the same time, and addressed the question of the epidemic.

\section{Ideologies for eliminating the epidemic}

After the CPC Central Committee's announcement (March 3, 1967 that the elimination of the epidemic was a political mission, both central and local governments paid significant attention to the disease, and were willing to spend money and provide resources for preventive programs. ${ }^{48}$ The CPC Central Committee used two slogans and two ideologies to fight the disease: 1) "Accelerate the revolution, increase production" (zhua geming cu shengchan) and 2) The "Patriotic Health Campaigns" (Aiguoweisheng) already mentioned and used in the context of the Korean War and the schistosomiasis campaigns.

When the Cultural Revolution was launched, agricultural and industrial production suffered. An article published in the People's Daily on September 6, 1966, specified that "the Cultural Revolution is the main focus; we must revolutionize and produce at the same time without any delay." ${ }^{49}$ The slogan "Accelerate the revolution, increase production," one of the main ideologies of the revolution, was emphasized in a People's Daily article published on September 7, 1966, following Mao's instructions, where it was stated that revolution and production should not be delayed..$^{50}$

Increasing agricultural and industrial production required a healthy population and effective disease control. As a result, the control and preventive measures of the epidemic also became a significant part of the supreme instruction of the third five-year plan (implemented by the CPC during 19661970). Applying the slogan, local authorities put the disease at the center of their activities. For instance, a prevention and treatment notice published in Guangxi Province explained:

47. CCP Documents of the Great Proletarian Cultural Revolution 1966-1967 1968 (19.03.1967): 377.

48. Zhonggong zhongyang guowuyuan zhishi 1967: 1 .

49. Zhonggong zhongyao lishi wenxian ziliao huibian 1997, vol. 13, no. 2: 18.

50. “Zhua ge ming cu sheng chan" 1966: 1. 
Apply all effective measures to eliminate diseases that affect people's health so that we can effectively implement revolution and increase production in order to ensure a smooth proletarian Cultural Revolution. [...] According to Chairman Mao's indication to accelerate revolution and increase production, we must pursue a proletarian Cultural Revolution and actively prevent and treat diseases so that the revolution will run smoothly, this is vital to the development of industrial and agricultural production. [...] To prevent and treat meningitis is not a general problem, the problem is to implement the Cultural Revolution and increase production. ${ }^{51}$

The fight against the epidemic was also incorporated into the Patriotic Health Campaigns mentioned above. The Patriotic Health Campaigns, since their implementation in 1952, had aimed to "motivate everyone (dongyuan qilai), decrease disease (jianshao jibing), make changes in customs (yifeng yisu), make changes to the country (gaizai guojia)," and fight for the protection of health and to prevent diseases. The CPC regarded the treatment of disease as a way of increasing the strength of the population, and moving forward from a backward stage to a more advanced level. Public health was seen as a strategy to increase productivity, develop industrial and agricultural production, and eventually improve living standards. ${ }^{52}$ After the end of the Korean War, the focus of the Patriotic Health Campaigns, once restricted to fighting the United States' alleged biological weapons, became the more general concern of public health and hygiene, and introduced the idea of public health and hygiene as an ongoing, everyday activity. Every household had to clean its home, and everyone was made highly aware of hygiene.

Since the 1950 s, committees had been operating in every province and city in China to promote, advertise and organize the Patriotic Health Campaigns. Under orders from Chairman Mao and the CPC Central Committee, the campaign essentially mobilized the general public to participate in a national movement for hygiene and disease prevention. It believed that mobilizing the masses, through the spirit of revolution, could be used to solve any post-1950s public health problem. In 1967, the central and local authorities mobilized the masses to carry out preventive measures for cerebrospinal meningitis specifically under the Patriotic Health Campaigns, promoting notably the slogan of Sankai (three opennesses), Sanshai (three sun-dryings), and Sangeli

51. "Guanyu qieshi zuohao fangzhi liuxingxing naojisuimoyan gongzuo de jinji tongzhi" 1967: 1.

52. Xiao 2004: 498-514. 
(three isolations) ${ }^{53}$ This preventive campaign was the major measure taken by the Patriotic Health Campaigns during the winter and spring. ${ }^{54}$

\section{The central and local strategic policy against epidemic cerebrospinal meningitis}

On March 3, 1967, the State Council, (according to an epidemic prevention report, submitted by the Ministry of Health), instructed local authorities at all levels to take immediate action to control the disease. ${ }^{55}$ In February 1967, initiating the preventive measures in every province and teaching the public how to prevent the disease were significant steps in controlling the epidemic. In Hunan province for instance, the following prevention efforts were made: firstly, the CPC Central Committee and the State Council provided medical support, sending medical staff and drugs to the Hunan province (indicating cooperation between the Ministry of Health, the Ministry of Communications, the Department of Railways, and the Department of Commerce). Secondly, Local epidemic elimination offices were established at all levels of government, including provincial, city, county government, community, and production brigade. The offices above the county level were led by military officers, and the duties of each office were clearly assigned. Thirdly, data collected about the epidemic were shared, and a large-scale promotion campaign was launched. Finally, 800 health teams composed of 12,799 medical staff were created, and sent to villages to promote the preventive program, and to treat any patients. From late February to April, a total of 429 patients had been treated..$^{56}$

It is worth noting that some difficulties were also encountered. The disease had spread throughout the villages in Hunan province, but the village health organizations could not control the epidemic due to a lack of preventive measures and necessary drugs. ${ }^{57}$ China also lacked other medical supplies,

53. "Three opennesses," "three sun-dryings," and "three isolations" are preventive measures designed to confront the epidemic. "Three opennesses" includes: 1) building more windows in the house; 2) enlarging the size of the windows; and 3) keeping windows open frequently. "Three sun-dryings" consists of: 1) drying clothes in the sun; 2) drying beds in the sun; and 3) sunbathing. Finally, "three isolations" involves the isolation of 1) patients; 2) relatives; and 3) the community.

54. Hubeisheng weisheng fangyizhan 1967: 9; Zhangjiakou zhuanqu fangbing office no publication data: 4-5; "liunao de yufang" 1967: 11-12.

55. “Zhonggong zhongyang guowuyuan zhishi” 1967: 1.

56. "Quansheng fangzhi liuxingxing naojisuimoyan gongzuo zongjie" 1967: 26-32.

57. "Quansheng fangzhi liuxingxing naojisuimoyan gongzuo zongjie" 1967: 26-32. 
such as face masks. ${ }^{58}$ For example, many medical staff in Guangzhou hospitals became infected with the disease when attending meningitis patients. Many county and city hospitals of Guangdong province urgently requested more money to purchase medical tools and drugs, especially first-aid supplies and sulfa drugs. However, local governments did not have enough funding to support the preventive work and treatment of the disease, to purchase the medicines and to pay medical staff. ${ }^{59}$

In February and March 1967, after receiving orders from the highest command of the CPC Central Committee, control centers were established in every province, county and city. These control centers had the role of coordinating prevention efforts, notably by printing and distributing health care handbooks of various forms, and treating meningitis. ${ }^{60}$ In August 1967, a handbook entitled, The Prevention and Treatment Handbook of Epidemic Cerebrospinal Meningitis, was co-edited by the Sanitation and Anti-epidemic Station, the Children's Hospital, the Beijing First Hospital of Infectious Diseases and the Beijing Second Hospital of Infectious Diseases, and the Chinese Medical Association. This book is divided into three sections: 1) prevention, 2) diagnosis, and 3) treatment (instructions relating to using sulfur drugs, penicillin and chloramphenicol). It emphasized the importance of preventive measures and also that the government had a significant role to play in health education relating to the disease and in mobilizing public participation. If one compares this handbook with Wang Qihuang's book (1961), it is clear that this publication further emphasized prevention, including: monitoring the health of people who had been in close contact with patients; providing adequate medical supplies for them; and even advocating the quarantining of epidemic areas in order to decrease the spread of the disease. Finally, the handbook stresses that the public should minimize the possibility of contact with people infected by the disease. For example, in areas where the disease was prevalent, the book advised that people stop public assemblies and cultural/entertainment activities. It recommended that affected villages and production brigades should be isolated if necessary. ${ }^{61}$

58. Deng 2006: 623 .

59. "Xian fangzhi liunao gongzhu huiyijiyao" 1967: 18; "Dui liunao fengzhi youguan wenti de yijian" 1967: 26-27; "Xian junguan weisheng xiaozu guanyu canjia yufang lounao yiwu renyuan xiangshou baojian jintie wenti de lianhe tongzhi” 1967: 90.

60. Deng 2006: 623.

61. The Sanitation and Anti-epidemic Station 1967. 


\section{The political struggles among the different factions within the CPC delay the implementation of public health measures}

As numerous scholars have shown ${ }^{62}$, the complex power struggles that existed among the different political factions within the CPC at that time may explain why it took so long before any concrete evidence of cooperation between the CPC and the Ministry of Health could be seen.

At the beginning of the Cultural Revolution, most central government departments were seized, and government officials attacked by what was later known as the rebel factions (zao fan pai). At the beginning of the Cultural Revolution, these mass organizations criticized government officials suspected of revisionism and took over every government unit. The Ministry of Health was no exception. ${ }^{63}$ In August 1966, Tao Zhu (the vice-premier of the State Council and the head of the Central Publicity Department) was promoted to the Standing Committee of the CPC Politburo, and assisted Zhou Enlai in handling the daily affairs of state. Prior to February 1967, he was in charge of the Ministry of Health. However, he was attacked verbally by Jiang Qing and the rebel factions, which surrounded and took over the Ministry of Health. Qian Xinzhong, the Minister of Health, was dragged into the political struggle. However, he was powerless and could not do anything as he was trapped in a power struggle between Sun Zheng, the secretary of the Ministry of Health, and the rebel factions. While an office to eliminate the cerebrospinal meningitis epidemic had already been established, it could not function under these circumstances.

Premier Zhou Enlai was in a difficult situation: on the one hand, he could not oppose Chairman Mao directly and halt the Great Networking; on the other, he had no control over the Ministry of Health until February 1967, when he resumed the cerebrospinal meningitis epidemic control office to promote the prevention and treatment of meningitis. Zhou believed that this was the most urgent issue at that time, and that it should be addressed without delay. ${ }^{64}$

62. Taylor 2005; Scheid 2013: 243.

63. Deng 2006: 623.

64. Zhonggong zhongyao lishi wenxian ziliao huibian 1997, vol. 13, no. 7: 216-232; vol. 13, no. 7: 94-95; vol. 13, no. 7: 95-98. 


\section{Conclusion}

The nationwide cerebrospinal meningitis epidemic in China during 19661967 was largely triggered by political factors. The mass mobilization campaign of the Great Networking Movement, launched by the CPC in the first stages of the Cultural Revolution, led over ten million students and Red Guards to travel across the country to share revolutionary experience and worship Mao. All mass pilgrimages facilitate the spread of disease. In this case the 'pilgrimage' initially focused on Beijing and the sacred places of the communist party, and later the 'pilgrims' travelled throughout the country, even to the remote rural corners, unwittingly spreading the disease. The gathering of crowds, the huge number of travelling students and the period of the year (winter/spring) when this mobilization took place contributed to the rapid spread of epidemic cerebrospinal meningitis throughout the country. Once the disease was so widespread, the epidemic was difficult to contain, not least because of the political struggles among political factions in the CPC which prevented the ending of the mass mobilization movement and the implementation of public health measures.

Tracing the history of the cerebrospinal meningitis epidemic at the beginning of the Cultural Revolution, this paper has found a collective memory of the period in which Zhou Enlai developed his heroic image of saving the people from the epidemic. On March 28, 2008, a stele titled Premier Zhou Enlai saves us (Zhou Enlai zongli jiumin beiji) was placed in Dabu county, in Meizhou, Guangdong province. The inscription illustrates the severe epidemic in Dabu county in early 1968. The stele recalls that at that time a teenager sent an urgent telegram to Chairman Mao, reporting the severe epidemic situation. Once Premier Zhou read its contents, he immediately sent doctors to the epidemic area, and as a result, the disease was quickly and finally brought under control.

Is the story true? The author of this paper has no answer at the moment but hopes that more archives and information relating to this epidemic will be released. This will facilitate a deeper understanding of the socio-political situation of the time and the roles of the various actors in handling the epidemic. 
Epidemic Cerebrospinal Meningitis during the Cultural Revolution

\begin{tabular}{|c|c|c|c|c|}
\hline City/County & Case & $\begin{array}{l}\text { Incidence rate } \\
\text { (per } 10,000)\end{array}$ & Death & Source \\
\hline Shantou City & \begin{tabular}{|l|}
$991(1966)$ \\
$82664(1967)$ \\
$20973(1968)$ \\
\end{tabular} & $\begin{array}{l}11.87 \\
1036.61 \\
366.2 \\
\end{array}$ & \begin{tabular}{|l|}
100 \\
4102 \\
1608 \\
\end{tabular} & $\begin{array}{l}\text { Shantoushizhi } \\
\text { 1999: } 406 .\end{array}$ \\
\hline Zhongshan City & $2478(1967)$ & & 85 & $\begin{array}{l}\text { Zhongshanshizai } \\
\text { 1997: } 1330 .\end{array}$ \\
\hline Zhaoqing City & $23813(1966-67)$ & & 1570 & $\begin{array}{l}\text { Zhaoqingshizhi } \\
\text { 1999: 1213. }\end{array}$ \\
\hline Chenghai County & 8790 (1966-68) & \begin{tabular}{|l|}
1113.08 \\
$(1967)$ \\
\end{tabular} & $608(1966-68)$ & $\begin{array}{l}\text { Chenghaixianzhi } \\
\text { 1992: } 758 .\end{array}$ \\
\hline Conghua County & & 1056.35 & & $\begin{array}{l}\text { Conghuaxianzhi } \\
\text { 1994: } 939 .\end{array}$ \\
\hline Dabu County & \begin{tabular}{|l|}
$1309(1967)$ \\
$2162(1968)$ \\
\end{tabular} & & $\begin{array}{l}114(1967) \\
140(1968) \\
\end{array}$ & \begin{tabular}{|l} 
Dabuxianzhi 1992: \\
567.
\end{tabular} \\
\hline Deqing County & $2330(1967)$ & & 118 & \begin{tabular}{|l} 
Deqingxianzhi \\
1996: 666.
\end{tabular} \\
\hline Dianbai County & $9182(1966-67)$ & 1190 & 458 & $\begin{array}{l}\text { Dianbaxianzhi } \\
\text { 2000: } 953 \text {. }\end{array}$ \\
\hline Fengkai County & 1569 & & 70 & \begin{tabular}{|l} 
Fengkaixianzhi \\
1998: 838. \\
\end{tabular} \\
\hline Fengshun County & 5804 (1967) & 1574.98 & 250 & $\begin{array}{l}\text { Fengshunxianzhi } \\
\text { 1995: } 855 .\end{array}$ \\
\hline Fogang County & $\begin{array}{l}1230(1967) \\
223(1968)\end{array}$ & \begin{tabular}{|l|}
$695(1967)$ \\
$122(1968)$ \\
\end{tabular} & \begin{tabular}{|l|}
$78(1967)$ \\
$23(1967)$ \\
\end{tabular} & $\begin{array}{l}\text { Fogangxianzhi } \\
\text { 2003: } 839 .\end{array}$ \\
\hline Gaoming County & $12(1966)$ & & 3 & $\begin{array}{l}\text { Gaomingxianzhi } \\
\text { 1995: } 620 . \\
\end{array}$ \\
\hline Jiaoling County & $816(1967)$ & & 35 & $\begin{array}{l}\text { Jiaolingxianzhi } \\
\text { 1992: } 608 .\end{array}$ \\
\hline Jiexi County & \begin{tabular}{|l|}
$3068(1967)$ \\
$727(1968)$ \\
\end{tabular} & & \begin{tabular}{|l|}
$187(1967)$ \\
$69(1968)$ \\
\end{tabular} & \begin{tabular}{|l} 
Jiexisianzhi 1994: \\
538. \\
\end{tabular} \\
\hline Heyuan County & 2387 (1967) & & & $\begin{array}{l}\text { Heyuanxianzhi } \\
\text { 2000: } 1023 \text {. }\end{array}$ \\
\hline Heshan County & 1953 (1967) & 780 & 108 & \begin{tabular}{|l} 
Heshanxianzhi \\
2001: 606. \\
\end{tabular} \\
\hline Hua County & 2088 (1966-67) & & 127 & $\begin{array}{l}\text { Huaxianzhi 1995: } \\
802 \text {. }\end{array}$ \\
\hline Huaiji County & 4143 & & 410 & $\begin{array}{l}\text { Huaijixianzhi } \\
\text { 1993: } 680 .\end{array}$ \\
\hline Huiyang County & \begin{tabular}{|l|}
$69(1966)$ \\
$2267(1967)$ \\
$464(1968)$ \\
\end{tabular} & & 111 & $\begin{array}{l}\text { Huiyangshizhi } \\
\text { 2003: } 1438 \text {. }\end{array}$ \\
\hline Lechang County & & 378.72 & 3 & $\begin{array}{l}\text { Lechangxianzhi } \\
\text { 1994: } 474 .\end{array}$ \\
\hline
\end{tabular}


Fan Ka wai

\begin{tabular}{|c|c|c|c|c|}
\hline Lianjiang County & 2530 & & 179 & $\begin{array}{l}\text { Lianjiangxianzhi } \\
\text { 1995: } 672 .\end{array}$ \\
\hline $\begin{array}{l}\text { Liannan Yaozu } \\
\text { Zizhi County }\end{array}$ & 364 (1967) & 397.8 & 14 & $\begin{array}{l}\text { Liannan Yaozu } \\
\text { Zizhixianxianzhi } \\
\text { 1996: } 610 .\end{array}$ \\
\hline $\begin{array}{l}\text { Lianshan } \\
\text { Zhuangzu yaozu } \\
\text { zizhi County }\end{array}$ & 81 & 125 & 14 & $\begin{array}{l}\text { Lianshan } \\
\text { Zhuangzu Yaozu } \\
\text { Zizhixianzhi 1997: } \\
763 .\end{array}$ \\
\hline $\begin{array}{l}\text { Longchuan } \\
\text { County }\end{array}$ & 1314 & 270.18 & 147 & $\begin{array}{l}\text { Longchuanxianzhi } \\
\text { 1994: } 424 .\end{array}$ \\
\hline Luoding County & 1330 (1966) & & 122 & $\begin{array}{l}\text { Luodingxianzhi } \\
\text { 1994: } 606 . \\
\end{array}$ \\
\hline Mei County & & & 191 & $\begin{array}{l}\text { Meixianzhi 1994: } \\
\text { 981. }\end{array}$ \\
\hline $\begin{array}{l}\text { Nanxiong } \\
\text { County }\end{array}$ & 6636 & & 109 & $\begin{array}{l}\text { Nanxiongxianzhi } \\
\text { 1991: } 645\end{array}$ \\
\hline Panyu County & 3387 & 656.3 & 162 & $\begin{array}{l}\text { Panyushizhi 1995: } \\
834\end{array}$ \\
\hline Pingyuan County & 824 & & 50 & $\begin{array}{l}\text { Pingyuanxianzhi } \\
\text { 1993: } 606 .\end{array}$ \\
\hline Puning County & 11140 (1967) & 1270 & 506 & $\begin{array}{l}\text { Puningxianhi } \\
\text { 1995: } 602 .\end{array}$ \\
\hline Raoping County & $\begin{array}{l}155(1966) \\
5741(1967) \\
2542(1968) \\
\end{array}$ & & $\begin{array}{l}18(1966) \\
283(1967) \\
108(1968) \\
\end{array}$ & $\begin{array}{l}\text { Raopingxianzhi } \\
\text { 1994: } 890 .\end{array}$ \\
\hline $\begin{array}{l}\text { Ruyuan Yaozu } \\
\text { Zizhixian County }\end{array}$ & 155 & & & $\begin{array}{l}\text { Ruyuan yaozu } \\
\text { zizhixianzhi 1997: } \\
695 \\
\end{array}$ \\
\hline $\begin{array}{l}\text { Qingyuan } \\
\text { County }\end{array}$ & 3378 (1967) & 584.6 & 201 & $\begin{array}{l}\text { Qingyuanxianhi } \\
\text { 1995: 894. }\end{array}$ \\
\hline Sanshui County & 1546 (1967) & & 52 & $\begin{array}{l}\text { Sanshuixianzhi } \\
\text { 1995: } 1217 .\end{array}$ \\
\hline Shixing County & & 250.43 (1967) & & $\begin{array}{l}\text { Shixingxianzhi } \\
\text { 1997: } 843 \text {. } \\
\end{array}$ \\
\hline $\begin{array}{l}\text { Wengyuan } \\
\text { County }\end{array}$ & 1148 & & 51 & $\begin{array}{l}\text { Wengyuanxianzhi } \\
\text { 1997: } 776 \\
\end{array}$ \\
\hline Wuhua County & 10937 (1967) & 1886.9 & 426 & $\begin{array}{l}\text { Wuhuaxianzhi } \\
\text { 1991: } 551 .\end{array}$ \\
\hline Xinhui County & 9745 (1966-67) & 1414.6 & 266 & $\begin{array}{l}\text { Xinhuixianzhi } \\
\text { 1995: } 1002 .\end{array}$ \\
\hline Xinxing County & $1322(1967)$ & & 70 & $\begin{array}{l}\text { Xinxingxianzhi } \\
\text { 1993: } 614 .\end{array}$ \\
\hline Xinyi County & 4228 (1967) & & 340 & $\begin{array}{l}\text { Xinyixianzhi } \\
\text { 1993: } 854 .\end{array}$ \\
\hline
\end{tabular}


Epidemic Cerebrospinal Meningitis during the Cultural Revolution

\begin{tabular}{|l|l|l|l|l|}
\hline $\begin{array}{l}\text { Yangchun } \\
\text { County }\end{array}$ & $4452(1967)$ & & 312 & $\begin{array}{l}\text { Yangchunxianzhi } \\
1996: 886 .\end{array}$ \\
\hline $\begin{array}{l}\text { Yangjiang } \\
\text { County }\end{array}$ & $9008(1966-68)$ & & 418 & $\begin{array}{l}\text { Yangjiangxianzhi } \\
2000: 939 .\end{array}$ \\
\hline Yunan County & $22(1966)$ & $\begin{array}{l}7.7(1966) \\
955(1967)\end{array}$ & $\begin{array}{l}1(1966) \\
60(1967)\end{array}$ & $\begin{array}{l}\text { Yunanxianzhi } \\
1995: 839 .\end{array}$ \\
\hline Yunfu County & $1639(1967)$ & & 82 & $\begin{array}{l}\text { Yunfuxianzhi } \\
1995: 713 .\end{array}$ \\
\hline Zijin County & $2315(1967)$ & & 133 & $\begin{array}{l}\text { Zijinxianzhi 1994: } \\
798 .\end{array}$ \\
\hline
\end{tabular}

Figure 3. Incidence of cerebrospinal meningitis in Guangdong counties

\section{BIBLIOGRAPHY}

\section{Primary Sources}

\section{Political Archives}

CCP Documents of the Great Proletarian Cultural Revolution 1966-1967 (1968). Hong Kong, Union Research Institute.

- "Zhonggong zhongyang bangongting guowuyuan mishuting guanyu zuohao waidilaijing hongweibing zhanshi he geming shisheng lijing gongzuo de yifengxin" (A Letter of the Central Office and the Secretariat of the State Council Concerning Doing Well the Work for the Coming of Red Guard Fighters from other Places to Beijing and the Departure of the Revolutionary Teachers and Students from Beijing) 中共中央辦公廳、國務院秘書廳關於做好外地來京紅 衛兵戰士告革命師生離京工作的一封信 (12.11.1966): 96-97.

- "Zhonggong zhongyang guanyu nongcun wuchanjieji wenhua da geming de zhishi (can an)" (Directive of the CPC Central Committee Concerning the Cultural Revolution in the Countryside [Draft]) 中共中央關於農村無產階級文 化大革命的指示 (草案) (15.12.1966): 137-138.

- "Zhonggong zhongyang guanyu tingzhi quanguoda de tongzhi" (Notice of the CPC Central Committee Concerning the Suspension of the Great Networking all over the Country) 中共中央關於停止全國大串連的通知 (19.03.1967): 377 .

- "Zhonggong zhongyang guanyu xian yi xia nongcun wenhua da geming de guiding" (Regulations of the CPC Central Committee Concerning the Cultural Revolution in the County Level) 中共中央關於縣以下農村文化大革命的規定 (14.09.1966): 77-78.

- $\quad$ "Zhonggong zhongyang, guowuyuan guanyu geming shisheng he Hongweibing jinxing buxing chuanlian wenti yu tongzhi” (Notice of the CPC Central Committee and the State Council Concerning the Question of Exchange of 
Revolutionary Experience on Foot by Revolutionary Teachers and Students, and Red Guards) 中共中央、國務院關於革命師生和紅衛兵進行步行串連問題與 通知 (03.02.1967): 225-226.

- "Zhonggong zhongyang, guowuyuan guanyu geming shisheng jinxing buxing chuanlian wenti yu tongzhi" (Notice of the CPC Central Committee and the State Council Concerning the Question of Revolutionary Teachers and Students Exchanging Revolutionary Experience) 中共中央、國務院關於革命師生進行 步行串連問題與通知 (16.11.1966): 107-108.

- “Zhonggong zhongyang, guowuyuan guanyu geming shisheng jinxing geming chuanlian wenti de buchong tongzhi" (Supplementary Circular of the CPC Central Committee and the State Council Concerning the Question of Exchange of Revolutionary Experience by Revolutionary Teachers and Students) 中共中 央、國務院關於革命師生進行革命串連問題的補充通知 (01.12.1966): 125126.

Zhonggong Zhongyao Lishi Wenxian Ziliao Huibian (Collection of Important Sources related to the History of Communist China) 中共重要歷史文獻資料匯編. 1997. Los Angeles, Zhongwen chubanwu fuwu zhongxin.

- $\quad$ "Chen Yi tongzhi jiuyue shisiri zai waiwenjiu quanti zhigong da hui shang de jiang hua (Comrade Chen Yi's Speech held in the Plenary Meeting of the Industrial Organization.14.09.1966) 陳毅同志九月十四日在外文局全體職工大會上的 講話.” Vol. 13, no. 2: 73.

- "Li Xiannian fuzongli jiejian sun qian huang ji bu jiguan gepai de jianghua" (Discourse among Vice-Premier Li Xiannian, Sun, Qian, Huang and All Factions during Li’s Reception. 09.03.1967) 李先念副總理接見孫、錢、黃及部機關各 派的談話. Vol. 13, no. 7: 94-95.

- $\quad$ "Li Xiannian fuzongli jiejian weishengbu jiguan ge qunzhong zuzhi daibiao shi de jianghua” 李先念副總理接見衛生部機關各群眾組織代表時的講話 (Speech Given by Vice- Premier Li Xiannian While Receiving the Representatives of All Mass Organizations of the Ministry of Health.10.03.1967). Vol. 13, no. 7: 95-98.

- "Qi Benyu tongzhi jiuyue liuri zai er qi jichechang gongju chejian jianghua jiyao" (Summary of Speech Given by Comrade Qi Benyu at Tool Room of the Feb. 7th Locomotive Works on 6 Sept. 6.09.1966) 戚本禹同志九月六日在二七機車廠 工具車間講話紀要. Vol. 13, no. 2: 18 .

- "Tao Zhu shiyue ershisiri zai zhongnanhai jiejian shoudu dazhuan yuanxiao hongweibing geming zaofan zongsilingbu bufen xuexiao daibiao shi de jianghua" (Tao Zhu Received the Representatives of Capital Higher Education Institutes' Red Guards in Revolutionary Rebels General Headquarters at Zhongnanhai on 24 Oct. 24.10.1966) 陶鑄十月二十四日在中南海接見首都大專院校紅衛兵革 命造反總司令部部分學校代表時的講話. Vol. 13, no. 2: 240.

- "Wu de tongzhi zai gongren tiyuguan guan yu jiedai waidi geming shisheng de jianghua” 吳德同志在工人體育館關於接待外地革命師生的講話 (Comrade Wu De's Speech Regarding the Reception of Revolutionary Teachers and Students from Other Places at the Workers' Stadium. 13.12.1966). Vol. 13, no. 4: 56-57. 
- "Zhang Chunqiao tongzhi zai zhengxie litang de jianghua" (Comrade Zhang Chunqiao's Speech at the People's Republic of China Political Consultative Auditorium. 28.10.1966) 張春橋同志在政協禮堂的講話. Vol. 13, no. 2: 265.

- “Zhou Enlai dui shoudu gaoxiao hongweibing de jianghua” (Zhou Enlai’s Speech to the Capital Higher Education Institutes’ Red Guards. 9.12.1966) 周恩來對首 都高校紅衛兵的講話. Vol. 13, no. 4: 74 .

- “Zhou Enlai tongzhi zai zhongyang gongzuo huiyi de jianghua" (Comrade Zhou Enlai’s Speech at the Central Work Conference. 28.10.1966) 周恩來同志在中央 工作會議上的講話. Vol. 13, no. 2: 268-270.

- "Zhou zongli dui jiedai renyuan de jianghua" (Premier Zhou's Speech to the Receptionists. 12.01.1967) 周總理對接待人員的講話. Vol. 13, no. 5: 129.

- "Zhou zongli ji er yue jiu ri de jianghua" (Premier Zhou's Speech on 9 Dec. 09.12.1966) 周總理十二月九日的講話. Vol. 13, no. 4: 73-76.

- "Zhou zongli jiejian weishengbu hongsezaofantuan hongqizhandoutuan gelianzongbu dongfanghonggongshe sige zuzhi daibiao he bulingdao shi jianghua" (Premier Zhou's Speech to the Four Organizational Representatives and Leaders of Red Regiment of Rebellion, Red Flag Combat Regiment, Revolutionary Union and East Is Red Commune, of the Ministry of Health. 24.03.1967) 周總理接見衛 生部紅色造反團、紅旗戰鬥團、革聯總部、東方紅公社四個組織代表和部 領導時講話. Vol. 13, no. 7: 216-232.

Archives about the Epidemic from Guangdong Provincial Archives, Handbooks, and Press

"Dui liunao fangzhi youguan wenti de yijian" (Opinions Regarding the Question of the Prevention and Treatment of Epidemic Cerebrospinal Meningitis) 對流腦防治有 關問題的意見 (3 March 1967). Guangdong Provincial Archives no. 317-1-148: 26-27.

"Guanyu qieshi zuohao fangzhi liuxingxing naojisuimoyan gongzuo de jinji tongzhi" (Urgent Notice Prone to the Conscientiously Doing Well the Work to Prevent and Treat Epidemic Cerebrospinal Meningitis) 關於切實做好防治流行性腦脊髓膜 炎工作的緊急通知 (20.02.1967). In GUANGXI ZHUANGZU ZIZHIQU FANGZHI LIUNAO ZHIHUIBU 廣西壯族自治區防治流腦指揮部 and GUANGXI ZHUANGZU ZIZHIQU WEISHENG JIAOYUSUO 廣西壯族自治區衛生教育所 (eds.), Fangzhiliuxingxing naojisuimoyan shouce (Handbook for the Prevention and Treatment of Epidemic Cerebrospinal Meningitis) 防治流行性腦脊髓膜炎手冊. No publication data: 1-6.

“Hongweibing bupa yuanzheng nan” (The Red Guards do not Fear Long March) 紅衛 兵不怕遠征難. People's Daily, 22.10. 1966: 1 .

“Liunao de yufang” (The Prevention of Epidemic Cerebrospinal Meningitis) 流腦的預 防 (20.02.1967). In GUANGXI ZHUANGZU ZIZHIQU FANGZHI LIUNAO ZHIHUIBU 廣西壯 族自治區防治流腦指揮部 and GUANGXI ZHUANGZU ZIZHIQU WEISHENG JIAOYUSUO 廣西壯族自治區衛生教育所 (eds.), Fangzhiliuxingxing naojisuimoyan 
shouce (Handbook forthe Prevention and Treatment of Epidemic Cerebrospinal Meningitis) 防治流行性腦脊髓膜炎手冊. No publication data: 9-13.

"Quansheng fangzhi liuxingxing naojisuimoyan gongzuo zongjie" (Summary on the Works of the Provincial Prevention and Treatment of Epidemic Cerebrospinal Meningitis) 全省防治流行性䐳脊髓膜炎工作總結 (19.05.1967). In HUNANSHENG FANGZHI NAOMOYAN ZHIHUIBU and HUNANSHENG WEISHENGTING 湖南 省防治腦膜炎指揮部、湖南省衛生廳 (eds.), Hunansheng fangzhi liuxingxing naojisuimoyan jingyan huibian (Collection on the Experiences of the Prevention and Treatment of Epidemic Cerebrospinal Meningitis in Hunan Province) 湖南省 防治流行性腦脊髓膜炎經驗匯編. No publication data: 26-32.

"Xian fangzhi liunao gongzhu huiyijiyao" (Summary of Provincial Meeting of the Prevention and Treatment of Epidemic Cerebrospinal Meningitis) 省防治流腦 工作會議紀要 (13.04.1967). Guangdong Provincial Archives no. 317-1-148: 18.

"Xian junguan weisheng xiaozu guanyu canjia yufang lounao yiwu renyuan xiangshou baojian jintie wenti de lianhe tongzhi” (Joint Notice by Small Group of Health Provincial Military Officials Pertaining to Receiving Health Allowance for the Medical Staff Participating in the Prevention of Epidemic Cerebrospinal Meningitis) 省軍管衛生小組關於參加預防流腦醫務人員享受保健津貼問題 的聯合通知 (04.07.1967). Guangdong Provincial Archives no. 295-1-234: 90.

"Zhonggong zhongyang guowuyuan zhishi" (Central Committee and State Council Directive) 中共中央、國務院指示 (03.03.1967). In HUNANSHENG FANGZHI NAOMOYAN ZHIHUIBU and HUNANSHENG WEISHENGTING 湖南省防治腦膜炎指揮部、 湖南省衛生廳 (eds.), Hunansheng fangzhi liuxingxing naojisuimoyan jingyan huibian (Collection on the Experiences of the Prevention and Treatment of Epidemic Cerebrospinal Meningitis in Hunan Province) 湖南省防治流行性腦脊 髓膜炎經驗匯編. No publication data: 1 .

“Zhua ge ming, cu sheng chan” (Accelerate Revolution, Increase Production) 抓革命 促生產. People's Daily, September 7, 1966: 1.

“Zui jinji huxu jinji dongyuan qilai wei xunsu pumie liunao er douzheng” (We urge you to fight against Epidemic Cerebrospinal Meningitis) 最緊急呼吁一緊急動員起 來, 為迅速撲滅流腦而鬥爭 (07.02.1967), in HUBEIXIAN WEISHENG FANGYIZHAN 湖北省衛生防疫站 (ed.) (February 1967). Liuxingxingnaomoyan fangzhi shouce (Handbook for the Prevention and Treatment of Epidemic Cerebrospinal Meningitis) 流行性腦膜炎防治手冊. No publication data.

ZHANGJAKOU ZhUANQU FANGBING OFFICE 張家口專區防病辦公室 (ed.), Liunao fangzhi ziliao (Materials for the Prevention and Treatment of Epidemic Cerebrospinal Meningitis) 流腦防治資料. No publication data.

\section{Local Gazetteers}

Anhui shengzhi weishengzhi (Health Gazetteer of Anhui Province) 安徽省志衛生志. (1996). Hefei, Anhui renmin chubanshe.

Beijingzhi weishengzhi (Health Gazetteer of Beijing) 北京志.衛生志. (2003). Beijing, Beijing chubanshe. 
Chenghai xianzhi (Chenghai County Gazetteer) 澄海縣志 (1992). Guangzhou, Guangdong renmin chubanshe.

Conghua xianzhi (Conghua County Gazetteer) 從化縣志 (1994). Guangzhou, Guangdong renmin chubanshe.

Dabu xianzhi (Dabu County Gazetteer) 大埔縣志 (1992). Guangzhou, Guangdong renmin chubanshe.

Deqing xianzhi (Deqing County Gazetteer) 德慶縣志 (1996). Guangzhou, Guangdong renmin chubanshe.

Dianbai xianzhi (Dianbai County Gazetteer) 電白縣志 (2000). Beijing, Zhonghua shuju.

Fengkaixianzhi (Fangkai County Gazetteer) 封開縣志 (1998). Guangzhou, Guangdong renmin chubanshe.

Fengshun xianzhi (Fenghun County Gazetteer) 豐順縣志 (1995). Guangzhou, Guangdong renmin chubanshe.

Fogang xianzhi (Fogang County Gazetteer) 佛岡縣志 (2003). Beijing, Zhonghua shuju.

Gansu shengzhi weishengzhi (Health Gazetteer of Gansu Province) 甘肅省志衛生志. (1995). Lanzhou, Gansu wenhua chubanshe.

Gaomingxianzhi (Gaoming County Gazetteer) 高明縣志 (1995) Guangzhou, Guangdong renmin chubanshe.

Guangdong shengzhi weishengzhi (Health Gazetteer of Guangdong Province) 廣東省 志衛生志 (2003). Guangzhou, Guangdong renmin chubanshe.

Guangxi tongzhi yiliao weishengzhi (Health Gazetteer of Guangxi Province) 廣西通志 醫療衛生志 (1999). Nanning, Guangxi renmin chubanshe.

Guangzhou shizhi. Gongchandangzhi (1921-1990) (Guangzhou City Gazetteer. Record of Communist Party of China) 廣州市志. 共產黨志 (1997). Guangzhou, Zhonggong Guangzhoushiwei dangzhi bianzuan lingdao xiaozu bangongshi.

Hainan shengzhi weishengzhi (Health Gazetteer of Hainan Province) 海南省志衛生志 (2001). Beijing, Fangzhi chubanshe.

Heilongjiang shengzhi weishengzhi (Health Gazetteer of Heilongjiang Province) 黑龍 江省志衛生志 (1998). Ha'erbin, Heilongjiang renmin chubanshe.

Henan shengzhi weishengzhi (Health Gazetteer of Henan Province) 河南省志衛生志 (1991). Zhengzhou, Henan renmin chubanshe.

Heshan xianzhi (Heshan County Gazetteer) 鶴山縣志 (2001). Guangzhou, Guangdong renmin chubanshe.

Heyuan xianzhi (Heyuan County Gazetteer) 河源縣志 (2000). Guangzhou, Guangdong renmin chubanshe.

Huaiji xianzhi (Huaji County Gazetteer) 懷集縣志. (1993). Guangzhou, Guangdong renmin chubanshe.

Hua xianzhi (Hua County Gazetteer) 花縣志 (1995). Guangzhou, Guangdong renmin chubanshe.

Huiyang xianzhi (Huiyang County Gazetteer) 惠陽縣志 (2003). Guangzhou, Guangdong renmin chubanshe. 
Hunan shengzhi yiyao weishengzhi (Health Gazetteer of Hunan Province) 湖南省志醫 藥衛生志 (1998). Changsha, Hunan renmin chubanshe.

Jiangsu shengzhi weishengzhi (Health Gazetteer of Jiangsu Province) 江蘇省志衛生 志 (2003). Nanjing, Jiangsu renmin chubanshe.

Jiangxisheng weishengzhi (Health Gazetteer of Jiangxi Province) 江西省衛生志 (1997). Hefei, Huangshan shushe.

Jiaoling xianzhi (Jiaoling County Gazetteer) 蕉嶺縣志 (1992). Guangzhou, Guangdong renmin chubanshe.

Jiexi xianzhi (Jiexi County Gazetteer) 揭西縣志. (1994). Guangzhou, Guangdong renmin chubanshe.

Jilinshengzhi weishengzhi (Health Gazetteer of Jilin Province) 吉林省志衛生志 (1992). Changchun, Jilin renmin chubanshe.

Jinggangshanzhi (Jianggang Mountain Gazetteer) 井岡山志 (1997). Beijing, Xinhua chubanshe.

Lechang xianzhi (Lechang County Gazetteer) 樂昌縣志 (1994). Guangzhou, Guangdong renmin chubanshe.

Lianjiang xianzhi (Lianjiang County Gazetteer) 廉江縣志. (1995). Guangzhou, Guangdong renmin chubanshe.

Liannan Yaozu zizhi xianzhi (Liannan Yaozu Zizhi County Gazetteer) 連南瑤族自治縣 縣志 (1996). Guangzhou, Guangdong renmin chubanshe.

Lianshan Zhuangzu Yaozu zizhi xianzhi (Lianshan Zhuangzu Yaozu Zizhi County Gazetteer) 連山壯族瑤族自治縣縣志 (1997). Beijing, sanlian shudian.

Liaoning shengzhi weishengzhi (Health Gazetteer of Liaoning Province) 遼寧省志衛 生志 (1999). Shenyang, Liaoning renmin chubanshe.

Longchuan xianzhi (Longchuan County Gazetteer) 龍川縣志. (1994). Guangzhou, Guangdong renmin chubanshe.

Louding xianzhi (Louding County Gazetteer) 羅定縣志. (1994). Guangzhou, Guangdong renmin chubanshe.

Mei xianzhi (Mei County Gazetteer) 梅縣志. (1994). Guangzhou, Guangdong renmin chubanshe.

Nanxiong xianzhi (Nanxiong County Gazetteer) 南雄縣志. (1991). Guangzhou, Guangdong renmin chubanshe.

Panyu xianzhi (Panyu County Gazetteer) 番禺縣志. (1995). Guangzhou, Guangdong renmin chubanshe.

Pingyuan xianzhi (Pingyuan County Gazetteer) 平遠縣志. (1993). Guangzhou, Guangdong renmin chubanshe.

Puning xianzhi (Puning County Gazetteer) 普寧縣志. (1995). Guangzhou, Guangdong renmin chubanshe.

Qingyuan xianzhi (Qingyuan County Gazetteer) 清遠縣志. (1995). no publication data. Raoping xianzhi (Raoping County Gazetteer) 饒平縣志. (1994). Guangzhou, Guangdong renmin chubanshe.

Ruyuan Yaozu Zizhi xianzhi (Ruyuan Yaozu Zizhi County Gazetteer) 乳源瑤族自治縣 志. (1997). Guangzhou, Guangdong renmin chubanshe. 
Sanshui xianzhi (Sanshu County Gazetteer) 三水縣志.(1995). Guangzhou, Guangdong renmin chubanshe.

Shaanxi shengzhi weishengzhi (Health Gazetteer of Shaanxi Province) 陝西省志衛生 志. (1996). Xian, Shaanxi renmin chubanshe.

Shandongsheng weishengzhi (Health Gazetteer of Shandong Province) 山東省衛生志. (1992). Jinan, Shandong renmin chubanshe.

Shantou shizhi (Shantou City Gazetteer) 汕頭市志. (1999). Beijing, Xinhua chubanshe.

Shanxi tongzhi weisheng yiyaozhi weishengpian (Health Gazetteer of Shanxi Province) 山西通志衛生醫藥志衛生篇. (1997). Beijing, Zhonghua shuju.

Shixing xianzhi (Shixing County Gazetteer) 始興縣志. (1997). Guangzhou, Guangdong renmin chubanshe.

Sichuan shengzhi yiyao weishengzhi (Health Gazetteer of Sichuan Province) 四川省志 醫藥衛生志. (1995) Chengdu, Sichuan cishu chubanshe.

Wengyuan xianzhi (Wengyuan County Gazetteer) 翁源縣志. (1997). Guangzhou, Guangdong renmin chubanshe.

Wuhua xianzhi (Wuhua County Gazetteer) 五華縣志. (1991). Guangzhou: Guangdong renmin chubanshe.

Xinhui xianzhi (Xinhui County Gazetteer) 新會縣志. (1995). Guangzhou, Guangdong renmin chubanshe.

Xinjiang tongzhi weishengzhi (Health Gazetteer of Xinjiang Province) 新疆通志衛生 志. (1996). Wulumuqi, Xinjiang renmin chubanshe.

Xinxing xianzhi (Xinxing County Gazetteer) 新興縣志. (1993). Guangzhou, Guangdong renmin chubanshe.

Xinyi xianzhi (Xinyi County Gazetteer) 信宜縣志. (1993). Guangzhou, Guangdong renmin chubanshe.

Yangchunxianzhi (Yangchun County Gazetteer) 陽春縣志. (1996). Guangzhou, Guangdong renmin chubanshe.

Yangjiang xianzhi (Yangjiang County Gazetteer) 陽江縣志. (2000). Guangzhou, Guangdong renmin chubanshe.

Yunan xianzhi (Yunan County Gazetteer) 郁南縣志. (1995). Guangzhou, Guangdong renmin chubanshe.

Yunfu xianzhi (Yunfu County Gazetteer) 雲浮縣志. (1995). Guangzhou, Guangdong renmin chubanshe.

Zhongshan shizhi (Zhongshan City Gazetteer) 中山市志 (1997). Guangzhou, Guangdong renmin chubanshe.

Zijin xianzhi (Zijin County Gazetteer) 紫金縣志 (1994). Guangzhou, Guangdong renmin chubanshe.

Zhaoqing shizhi (Zhaoqing City Gazetteer) 肇慶市志.(1999). Guangzhou, Guangdong renmin chubanshe.

\section{Literature}

Baltimore Robert (2009). "Meningococcal Infections.” In Philip Brachman and Elias Abrutyn (eds.), Bacterial Infections of Humans. New York, Springer: 495-517. 
Bu Weihua 卜偉華 (2008). Zhonghua Renmin Gongheguo shi (The History of the People's Republic of China) 中華人民共和國史, vol. 6 (1966-1968). Hong Kong, Research Center for Contemporary Chinese Culture, Chinese University of Hong Kong.

CAREy Warren and Myles Maxfield. (1967). "Intelligence Implications of Disease." Center for the Study of Intelligence, Studies Archive Index 16, 2. Web. 5 Feb. 2014. < https://www.cia.gov/library/center-for-the-study-of-intelligence/kent-csi/ vol16no2/html/v16i2a06p_0001.htm >

Chan Anita (1985). Children of Mao: Personality Development and Political Activism in the Red Guard Generation. Seattle, University of Washington Press.

CHEN Xuewei 陳雪薇 (1987). “Jingji jianshe de tingzhi daotui jiqi lishi jiaoxun” (The Stagnation and Retrogression of Economic Construction and their Historical Lesson) 經濟建設的停滯、倒退及其歷史教訓. In Tan Zongji 譚宗級 and Qian Zheng 鄭謙 (eds.), Shinian hou de pingshuo: wenhua da geming shi lunji (Comments after aDecade: Collected papers on the History of Cultural Revolution) 十年後的評說一文化大革命史論集. Beijing, Zhonggong dang shi ziliao chubanshe: 162 .

CHEN Meei-shia (2007). "The Great Reversal: Transformation of Health Care in the People's Republic of China.” In William C. Cockerham (ed.), The Blackwell Companion to Medical Sociology. Oxford, Blackwell: 456-482.

Cur Yueli (ed.) (1986). Public Health in the People's Republic of China. Beijing, People's Medical Publishing House.

Deng Tietao 鄧鐵濤 (ed.) (2006). Zhongguo fangyi shi (History of the Epidemic Prevention in China) 中國防疫史. Nanning, Guangxi kexue jishu chubanshe.

Denton Kirk (2012). "Yan'an as a Site of Memory in Socialist and Postsocialist China." In Marc Andre Matten (ed.), Places of Memory in Modern China: History, Politics, and Identity. Leiden, Brill: 233-281.

Endicott Stephen and Hagerman Edward (1998). The United States and Biological Warfare: Secrets from the Early Cold War and Korea. Bloomington, Indiana University Press.

FAN Ka wai (2010). "Mass Mobilization and the Anti-Schistosomiasis Campaign in Maoist China (1955-1960)." In Albin Holmgren and Gerhard Borg (eds.), Handbook of Disease Outbreaks: Prevention, Detection and Control. New York, Nova Science Publishers: 277-293.

FAN Ka wai and LAI Honkai (2008). "Mao Zedong's Fight Against Schistosomiasis." Perspectives in Biology and Medicine, vol. 51, no. 2: 176-187.

FUJIANSHENG WEISHENG FANGYI ZHAN YEWUKE 福建省衛生防疫站業務科 (1975). "Fujiansheng 23 nian de liunao yiqing fenxi" (A 23-year analysis of Epidemic Situation of Cerebrospinal Meningitis in Fujian Province) 福建省 23 年的流腦疫 情分析. Liuxingbing fangzhi yanjiu 流行病防治研究, no. 1: 37-42.

Ge Zhaoguang 葛兆光 (01.03.2011). “Tieliu hongliu yu mangliu: wo de 1966 nian chuanlian jishi” (The Iron Flood, Powerful Flood and Blind Flood: My Record of Great Networking in 1966) 鐵流、洪流與盲流一我的 1966 年大串聯紀事. 
Nanfang zhoumo 南方周末, vol. 1411. Web. 5 Feb 2014. < http://www.infzm. com/content/55671 >

Gross Miriam (2010). Chasing Snail: Anti-Schistosomiasis Campaigns in the People's Republic of China. Diss. University of California, San Diego. Ann Arbor, UMI.

Guo Jian, Song Yongyi and Yuan Zhou (2006). "Great Networking." Historical Dictionary of the Chinese Cultural Revolution. Lanham, The Scarecrow Press.

HEBEISHENG WEISHENG FANGYI ZHAN 河北省衛生防疫站(1975).Hebei 25 nian liuxingxing naojisuimoyan yiqing fenxi he yuce de chu bu tan tao (A 25-year preliminary Investigation of Epidemic Analysis and Anticipation of Cerebrospinal Meningitis in Hebei Province) 河北省 25 年流行性腦脊髓膜炎疫情分析和預測的初步探 討. Hebei weisheng fangyi 河北衛生防疫: 50-62.

Hipgrave David (2011). "Communicable Disease Control in China: from Mao to Now." Journal of Global Health, vol. 1, no. 2: 224-238.

Hu Yi (2013). Rural Health Care Delivery. Berlin, Springer.

Hu Zhen 胡真 (1981). "Liuxingxing naojisuimoyan liuxingbing xue jinzhan" (The Epidemiological Progress in Epidemic Cerebrospinal Meningitis) 流行性腦脊 髓膜炎流行學病進展. In Wu Kexi 吳科系 (ed.), Liuxingbing xue jinzhan (The Progress in Epidemiology) 流行病學進展, vol. 1. Beijing, Renmin weisheng chubanshe: 61.

Huang Shuze 黃樹則 and Lin Shixiao 林士笑 (eds.) (2009). Dangdai Zhongguo de weisheng shiye (Hygienic Work in Contemporary China) 當代中國衛生事 業. Beijing, Dangdai Zhongguo chubanshe and Hong Kong, Xianggang zuguo chubanshe.

HUNANSHENG WEISHENG FANGYI ZHAN 湖南省衛生防疫站 (1975). Hunan sheng er shi liu liunao yiqing ziliao fenxi baogao (A 26-year Analysis Report on Epidemic Materials of Cerebrospinal Meningitis in Hunan Province) 湖南省二十六年流 腦疫情資料分析報告. Hebei weisheng fangyi 河北衛生防疫: 63-75.

Hung Changtai (2010). "The Anti-Unity Sect Campaign and Mass Mobilization in the Early People's Republic of China." China Quarterly, vol. 202: 400-420.

Liu Wusheng 劉武生 (2006). Wenge zhong de Zhou Enlai (The Role of Zhou Enlai during the Cultural Revolution) 文革中的周恩來. Hong Kong, Sanlian shudian.

Lu Xiuyuan (1995). “A Step Toward Understanding Popular Violence in China's Cultural Revolution.” Pacific Affairs, vol. 67, no. 4: 533-542.

Macfarquhar Roderick and Schoenhals Michael (2006). Mao's Last Revolution. Cambridge, Belknap Press of Harvard University Press.

Moore Patrick, Harrison Lee, TelzaK Edward, Ajello Gloria and Broome Claire (1988). "Group A Meningococcal Carriage in Travelers Returning from Saudi Arabia." Journal of the American Medical Association, vol. 260, no. 18: 26862689.

National Immunization Program, Chinese Center for Disease Control and Prevention. Web. 5 Feb 2014. < http://www.chinanip.org.cn/xxyd/jbzs/201211/ t20121127_72225.htm >

PATTERSON David (1993). "Meningitis." In Kenneth Kiple (ed.), The Cambridge World History of Human Disease. Cambridge, Cambridge University Press: 878. 
Rogaski Ruth (2004). Hygienic Modernity: Meanings of Health and Disease in TreatyPort China. Berkeley, University of California Press.

SAEZ-LIOREnS Xavier and George McCracken (2003). "Bacterial Meningitis in Children." Lancet, vol. 361, no. 9375: 2139-2148.

SCHEID Volker (2013). “The People's Republic of China.” In T. J. Hinrichs and Linda Barnes (eds.), Chinese Medicine and Healing. Cambridge, The Belknap Press of Harvard University Press: 239-283.

Schwartz Benjamin, Patrick Moore and Claire Broome (1989). "Global Epidemiology of Meningococcal Disease.” Clinical Microbiology Reviews, vol. 2S: S 118-124.

TAYLOR Kim (2011). Chinese Medicine in Early Communist China, 1945-1963: A Medicine of Revolution. Routledge, Needham Research Institute Series.

The Sanitation and Anti-Epidemic Station, Children's Hospital, The First Lazaretto and The Second Lazaretto of Beijing and Chinese Medical Association (eds.) (1967). Liuxing xingnaojisuimoyan fangzhi shouce (Handbook for the Prevention and Treatment of Epidemic Cerebrospinal Meningitis) 流行性腦脊髓膜炎防治 手冊. Beijing, Renmin weisheng chubanshe.

UMAru Emmanuel Tanko, Ludin Ahmed Nazri Muhamad, MAJID Mohammed Rafee and SABRI Soheil (2013). "Risk Factors Responsible for the Spread of Meningococcal Meningitis.” International Journal of Education and Research, vol. 1, no. 2: 1-30. WALDER Andrew (2009). Fractured Rebellion: the Beijing Red Guard Movement. Cambridge, Harvard University Press.

Wang Jianfu, Dominique Caugant, Li Xinwu, Hu Xujing, Poolman Jan, Crowe Brian and Achtman Mark (1992). "Clonal and Antigenic Analysis of Serogroup A Neisseria meningitidis with Particular Reference to Epidemiological Features of Epidemic Meningitis in the People's Republic of China." Infection and Immunity, vol. 60, no. 12: 5267-5282.

WANG Qihuang 王者煌 (1961). Liuxing xing naomoyan de fangzhi (The Prevention and Treatment of Epidemic Cerebrospinal Meningitis) 流行性腦膜炎防治. Beijing, Renmin weisheng chubanshe.

WANG Yi 王毅 (1996). “Wanwu shengzhang kao taiyang yu yuanshi chongbai” (All Things on Earth Growing Relies on Sun and Primitive Worship) 萬物生長靠太陽 與原始崇拜. In Liu Qingfeng 劉青峰 (ed.), Wenhua da geming: shishi yu yanjiu (Cultural Revolution: Historical Facts and Research) 文化大革命：史實與研 究. Hong Kong, Chinese University Press: 127-138.

WANG Youqin 王友琴 (1996). “1966: Xuesheng Dalaoshi de Geming” (Student Attacks Against Teachers: the Revolution of 1996) 學生打老師的革命. In Liu Quingfeng 劉青峰 (ed.), Wenhua da geming: shishi yu yanjiu (Cultural Revolution: Historical Facts and Research) 文化大革命：史實與研究. Hong Kong, Chinese University Press: 17-36.

White Lynn (1989). Policies of Chaos: the Organizational Causes of Violence in China's Cultural Revolution. Princeton, Princeton University Press.

World Health Organization (1998, 2d edition). Control of Epidemic Meningococcal Disease. Practical Guidelines. Geneva, World Health Organization. Web. 5 
Feb 2014. > http://www.who.int/csr/resources/publications/meningitis/ whoemcbac983.pdf >

Wu Xujing 胡緒敬 (1991). “Woguo liunao zhouqixing liuxing tezheng de yanjiu" (Study on Periodically Prevalent Feature of Epidemic Cerebrospinal Meningitis in China) 我國流腦周期性流行特徵的研究. Chinese Journal of Epidemiology, vol. 12, no. 3: 136-139.

XIAO Aishu 蕭愛樹 (2004). “1949-1959 nian aiguo weisheng yundong” (The Patriotic Health Movement from 1949 to 1959) 1949-1959 年愛國衛生運動. In Li Wen 李文(ed.), Guoshi luncong (Collected Papers on Chinese History) 國史論叢. Beijing, Dangdai Zhongguo chubanshe: 498-514.

XuE Yuankun 薛元坤 (ed.) (2009). Liuxingxing naojisuimoyan (Epidemic Cerebrospinal Meningitis) 流行性腦脊髓膜炎. Beijing, Renmin weisheng chubanshe.

YAN Fan 燕帆 (1993). Dachuanlian:yichang shi wu qian li de zhengzhi luyou (Great Networking: an Unprecedented Political Journey) 大串連：一場史無前例的政 治旅遊. Beijing, Jingguan jiaoyu chubanshe.

YAN Jiaqi 嚴家其 and GAO Gao 高臬 (1989). Wenhua da geming shinian shi (A 10-year History of the Cultural Revolution) 文化大革命十年史. Hong Kong, Chaoliu chubanshe.

YANG Guobin (2000). "The Liminal Effects of Social Movements: Red Guards and the Transformation of Identity." Sociological Forum, vol. 15, no. 3: 379-406.

ZHANG Xincan 張新蚻 (2003). Hongse shao nu riji: 1966-1971 yige nu hongweibing de xinling huiji (Diary of a Red Girl: Spiritual Journey of a Female Red Guard) 紅 色少女日記: 1966-1971 一個女紅衛兵的心靈軌跡. Beijing, Zhongguo shehui kexue chubanshe.

ZHANG Zuoliang 張佐良 (1997). Zhou Enlai de zuihou shinian: yiwei baojian yisheng de huiyi (Zhou Enlai's Last Ten Years: Recollections of a Healthcare Doctor) 周恩 來的最後十年：一位保健醫生的回憶. Shanghai, Shanghai renmin chubanshe.

Zuo Wenyuan 迮文遠 (ed.) (1997). Jihua mianyi xue (Vaccines and Immunization) 計 畫免疫學. Shanghai, Shanghai kexue jishu wenxian chubanshe.

\section{GLOSSARY}

Aiguo weisheng 愛國衛生

Anhui 安徽

Beijing 北京

Changsha 長沙

Changshao 長韶

Chenghai xian 澄海縣

Chenzhou 椰州

Chongqing 重慶

Conghua xian 從化縣 
Fan Ka wai

Da chuan lian 大串連

Dabu (xian) 大埔(縣)

Daye 大冶

Dazhai 大寨

Deng Tietao 鄧鐵濤

Deqing xian 德慶縣

Dianbai xian 電白縣

Difangzhi 地方誌

dongyuan qilai 動員起來

Fengkai xian 封開縣

Fengshun (xian) 豐順(縣)

Fogang xian 佛岡縣

Fujian 福建

gaizai guojia 改造國家

Gansu 甘肅

Gaoming xian 高明縣

Guandu 官渡

Guangdong 廣東

Guangxi 廣西

Guangzhou 廣州

Hainan 海南

Hebei 河北

Heilongjiang 黑龍江

Henan 河南

Hengyang 衡陽

Heshan xian 鶴山縣

Heyuan xian 河源縣

Hong wei bing 紅衛兵

Hua (xian) 花(縣)

Huaiji xian 懷集縣

Huangshi 黃石

Hubei 湖北

Huiyang xian 惠陽縣

Hunan 湖南

Jiang Qing 江青

Jiangsu 江蘇

Jiangxi 江西

jianshao jibing 減少疾病

Jiaoling xian 蕉嶺縣

Jiexi xian 揭西縣 
Jilin 吉林

Jinggang Mountains 井岡山

Lechang xian 樂昌縣

Lianjiang xian 廉江縣

Liannan Yaozu Zizhi 連南瑤族自治

Lianshan Zhuangzu Yaozu zizhixian 連山壯族瑤族自治縣

Liaoning 遼寧

Longchuan xian 龍川縣

Luoding (xian) 羅定(縣)

Mao Zedong 毛澤東

Meixian 梅縣

Meizhou 梅州

Nanxiong xian 南雄縣

Ningxia 寧夏

Panyu xian 番禺縣

Pingyuan (xian) 平遠(縣)

Puning xian 普寧縣

Qian Xinzhong 錢信忠

Qinghai 青海

Qingyuan xian 清遠縣

Quanguo dachuanlian 全國大串連

Raoping (xian) 饒平(縣)

Renmin gongshe 人民公社

Renmin ribao 人民日報

Ruyuan Yaozu zizhi xian 乳源瑤族自治縣

Sangeli 三隔離

Sankai 三開

Sanshai 三喈

Sanshui (xian) 三水(縣)

Shaanxi 陝西

Shandong 山東

Shanghai Ruijin 上海瑞金

Shantou 汕頭

Shanxi 山西

Shaoshan 韶山

Shixing xian 始興縣

Si Jiu 四舊

Sichuan 四川

Sun Zheng 孫正

Tao Zhu 陶鑄 
Fan Ka wai

Tiananmen 天安門

Wang Qihuang 王耆煌

Weishengzhi 衛生志

Wengyuan (xian) 翁源(縣)

Wuhua (xian) 五華(縣)

Xinhui (xian) 新會(縣)

Xinjiang 新疆

Xinxing xian 新興縣

Xinyi xian 信宜縣

Yan'an 延安

Yangchun (xian) 陽春(縣)

Yangjiang xian 陽江縣

yifeng yisu 移風易俗

Yueyang 岳陽

Yunan xian 郁南縣

Yunfu xian 雲浮縣

Zao fan pai 造反派

Zhaoqing 肇慶

Zhongshan 中山

Zhou Enlai zongli jiumin beiji 周恩來總理救民碑記

Zhou Enlai 周恩來

Zhoubei 周陂

zhua geming, cu shengchan 抓革命, 促生產

Zhuzhou 株洲

Zijin xian 紫金縣

Zunyi 遵義 